\title{
Evaluation of a simplified calculation approach for final heating energy use in non-residential buildings
}

\author{
B. Wauman ${ }^{1}$, W. Parys ${ }^{2,3}$, H. Breesch ${ }^{1}$ and D. Saelens ${ }^{3,4}$ \\ ${ }^{1}$ KU Leuven, Department of Civil Engineering, Construction Technology Cluster, Sustainable \\ Building, Technology Campus Ghent, Gebroeders De Smetstraat 1, B-9000 Gent, Belgium \\ ${ }^{2}$ Bauphi, Stropkaai 55, B-9000 Gent, Belgium \\ ${ }^{3}$ KU Leuven, Department of Civil Engineering, Building Physics Section, Kasteelpark Aren- \\ berg 40 - box 2447, B-3001 Heverlee, Belgium \\ ${ }^{4}$ EnergyVille, Thor Park 8310, 3600 Genk, Belgium \\ Hilde.Breesch@kuleuven.be
}

\begin{abstract}
.
In Flanders, an obligatory software tool (EPR) is used to assess the energy performance of new buildings offering a simplified procedure to estimate the energy use for heating. This calculation approach is based on the principle of multiplying the building's heating demand with standardized (sub)system efficiencies. In this paper, the accuracy of this simplified approach is assessed for a traditional, hydronic heating system in non-residential buildings. To do so, integrated dynamic simulations are performed in TRNSYS for a series of building design variants with varying insulation quality, thermal capacity, window-to-wall ratio and orientation. From the integrated simulations, monthly subsystem efficiencies are deduced. Results show that the efficiencies are significantly influenced by the part load ratio. As however losses of efficiencies are noticed only in periods of low heat demands, the overall effect on the annual use is limited. Energy assessment by the simplified method is within an error of $<2.5 \mathrm{kWh} /(\mathrm{m} 2 . \mathrm{a})$ or $<10 \%$. Therefore, the simplified approach as currently applied in the EPR calculation tool in Flanders is concluded to be suited for the calculation of the final energy use. An evaluation of tabulated values for the overall system efficiencies used in this simplified method is however recommended.
\end{abstract}

Keywords: Energy use assessment for heating; Integrated building and HVAC system simulations; non-residential buildings.

\section{Introduction}

In the recently approved second recast of the Energy Performance of Buildings Directive [1] the European Union commits itself to develop a sustainable, competitive, secure and decarbonised energy system by 2050. An important aspect to achieve this goal is to find a cost-efficient equilibrium between decarbonising energy supplies and reducing final energy consumption of the building stock. This chapter focusses on the 
final energy use of non-residential buildings. To significantly reduce this energy consumption by 2050 , the application of a reliable and accurate method for the energy use assessment of building designs is essential. In Flanders, an obligatory software tool (EPR) is used to assess the energy performance of new buildings. The energy performance of a building is determined based on calculated energy use reflecting typical energy use for heating, cooling, domestic hot water, ventilation and built-in lighting and other technical systems. The EPR-tool consists of two main parts: one aimed at residential buildings [2] and one aimed at school and office buildings [3]. Both parts use the same calculation method and determine the energy performance of a building design in three consecutive steps: (i) the calculation of the net energy demand for heating and cooling, (ii) the calculation of the delivered energy to the heating and cooling systems as the division of the energy demand by the annually averaged, tabulated subsystem efficiencies for generation, storage, distribution, control and emission and (iii) the calculation of the primary energy use by adding the auxiliary energy needed for all system components and converting it to primary energy, taking into account renewable energy sources and national conversion factors which represent the conversion step from energy source to energy carrier. The energy balances are hereby calculated in steady-state conditions on a monthly time-base. Particularly in the context of building energy regulations, the simplicity of the input, the transparency of the calculation rules, the intuitive correlation between input and output, the robustness and reproducibility of the quasi-steady-state method are considered as a great advantage compared to the more complex dynamic simulation tools [4,5]. On the other hand, dynamic effects are taken into consideration in a simplified way by time weighted averaged values and empirically determined correction factors. Moreover, a simplified calculation approach is used to determine the final energy use. Each of the HVAC subsystems are evaluated separately and the subsystems' thermal losses are calculated in a simplified way using tabulated efficiencies. These tabulated values are based on the related HVAC system's components but are generally irrespective of the building characteristics and neglect the mutual interplay between the various subsystems.

The EPR-tool attempts to predict the buildings' energy use as accurately as possible. However, the inherent model assumptions and simplifications might (over)simplify the dynamic and nonlinear interaction of the building and HVAC systems which may jeopardise the accuracy and the use of the method in the context of energy regulation. After all, to ensure the objectives of the building energy policy and guarantee the EPB Directives effectiveness, the quasi-steady-state calculation results should be accurate and reliable. Moreover, as the EPR tool is used for the execution of cost-optimal studies [6,7] in the context of EPBD and hence is used as a supporting tool for energy policy decision making, the calculation results should be realistic to avoid inaccurate cost-optimal design solutions and inefficient energy saving measures which could affect in turn the evolutions and trends on the building market [8]. As argued by $[9,10]$ an integrated approach is therefore better suited, where a dynamic simulation is set up that includes 
both the building and the system. Though holistic studies on HVAC system performance characterisation are rather rare [11], this approach has been successfully adopted in a few studies, illustrating the influence of the building and the building use on the HVAC system efficiency.

Korolija [12] simulated a large amount of office buildings varying in orientation, insulation, glazing-to-wall ratio, glazing type, structural shading and day lighting coupled to four types of secondary HVAC systems for several weather data files using the integrated approach. The results indicated clearly that the annual heating and cooling system efficiency and the annual auxiliary energy use for the different systems are not constant, but depend instead on the (thermal) characteristics of the building and on the building loads. Similarly, $[10,13,14]$ demonstrated the relation between the insulation quality of the building envelope and the emission and distribution efficiency of heating systems in residential buildings. A rather strong relationship between the monthly total efficiency and the heat-balance ratio of the building - the ratio of heat gains over heat losses - was found. This effect is attributed to component efficiencies decreasing for lower part load ratios and overheating due to imperfect control occurring mainly when heating demand is low. [15] established correlations between the heat emission and control efficiency and a parameter characterising the building properties for different combinations of systems. His findings were integrated in the German standard [16].

In line with these studies, this paper uses an integrated approach to evaluate the accuracy of the EPR-tool, focusing on schools and office buildings in particular [3]. To do so, the results from two similar but separate, larger studies - one on school buildings [17] and one on office buildings [18] are brought together. Moreover, this paper focuses on the final energy use for heating. After all, in Flemish schools, heating is the most important contributor to the total energy use whereas active cooling ${ }^{1}$ and (de)humidification are rare [17]. At the same time, a study from 2001 [19] which analyses in detail 50 recently renovated and constructed offices spread out over Flanders and hence demonstrates the market penetration at that time, shows that $20 \%$ of office buildings are built without an active cooling system.

To assess the accuracy of the simplified calculation method used in the EPR-tool, integrated building and HVAC system simulations of a relatively simple heating system commonly found in office and school buildings in Flanders are performed in TRNSYS. In extension to the research carried out by [20], both the primary and secondary HVAC system are modelled. The aim of this paper is to analyse the monthly subsystem efficiencies calculated with this integrated approach and to express them depending on building characteristics, in analogy with the work of $[10,13]$ for residential buildings, to acknowledge the influence of the building and building use on the HVAC system performance. The influence of these subsystem efficiencies on the EPR calculation results is then assessed to evaluate the accuracy of the simplified calculation approach.

1 Flanders has a temperate maritime climate influenced by the North Sea and the Atlantic Ocean with relatively moderate summers and mild winters. Moreover, schools are closed during July and August. 


\section{Terminology}

\subsection{Conceptual scheme}

A heating system consists generally of four subsystems: a generation, storage, distribution and emission subsystem. The first two subsystems form the primary HVAC system, while the latter two form the secondary HVAC system.

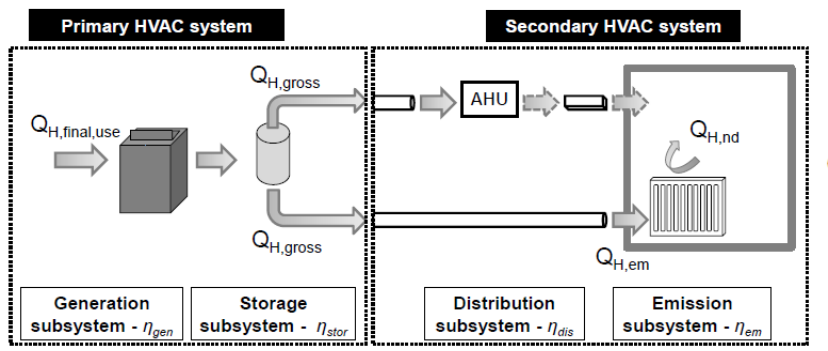

(a) Sankey diagram heating energy flows

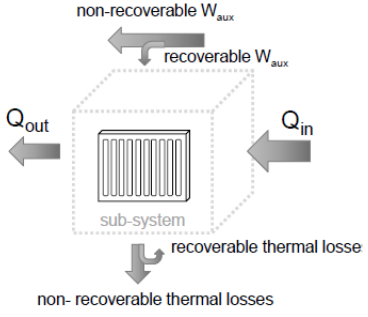

(b) Sub-system energy flow [21]

Fig. 1. Conceptual scheme of the simplified calculation procedure as currently applied in the EPR calculation tool [3].

To calculate the final energy use for heating, the EPR calculation tool [3] applies a sequential subsystem calculation approach (see Figure 1 (a)). Thermal losses are calculated separately for each of the included subsystems using tabulated subsystem efficiencies. The recoverable part of the thermal losses is hereby directly subtracted from the loss of each system and are thus accounted for by an increase of the related subsystems' efficiencies (see Figure 1 (b)). This method is intuitive and simple as no iterations are needed to simulate the performance of the building and its system. According to EPR, the final energy use for heating $\mathrm{Q}_{\mathrm{H} \text {,final,use }}$ is calculated in two steps. First, the gross energy demand $\mathrm{Q}_{\mathrm{H} \text {,gross }}$ is calculated which is the energy needed to be delivered by the generation system or plant to the secondary HVAC system (see Figure 1 (a)). Next, the total energy delivered to the heating system $\mathrm{Q}_{\mathrm{H} \text {,final,use }}$ is calculated by dividing the gross energy demand $\mathrm{Q}_{\mathrm{H} \text {,gross }}$ by the generation efficiency $\eta_{\text {gen }}$ and the storage efficiency $\eta_{\text {stor. }}$.

\subsection{Calculation of the gross energy demand}

The calculation of the gross energy demand $\mathrm{Q}_{\mathrm{H} \text {,gross }}$ depends on the yearly averaged efficiency of the secondary HVAC system $\eta_{\text {system }}$ which covers both the waste of energy 
that occurs when a building is simultaneously heated and cooled, and the overall occurring thermal energy losses of the secondary HVAC system. General system efficiencies are calculated using Eq. 1:

$$
n_{\text {system }}=\frac{1}{1+a_{\text {heat }}+f_{\text {annih }} / f_{\text {heat }, \text { net }}}
$$

where $a_{\text {heat }}$ is a factor representing the heat losses due to distribution of heat and imperfect control of the heating system, $\mathrm{f}_{\text {annih }}$ is a factor accounting for the amount of wasted energy due to simultaneous heating and cooling, $f_{\text {heat,net }}$ is the ratio of $\mathrm{Q}_{\mathrm{H}, \mathrm{nd}}$ and the sum of $\mathrm{Q}_{\mathrm{H}, \mathrm{nd}}$ and $\mathrm{Q}_{\mathrm{C}, \mathrm{nd}}$.

An overview of all standard tabulated values for the aforementioned factors based on the type of the heat distribution medium and the applied control system can be found in the EPR calculation manual Table 9 and 10 [3].

\subsection{Calculation of the final energy demand}

The total energy input to the heat generation system $\mathrm{Q}_{\mathrm{H} \text {,final,use }}$ needed for the requested heating of the building is calculated using Eq. 2.

$$
Q_{H, \text { final }, \text { use }}=\frac{Q_{H, \text { gross }}}{\eta_{\text {gen }} \cdot \eta_{\text {stor }}}
$$

The source of generation efficiency losses depends highly on the type of generation device. For boilers for example, efficiency losses are caused by heat transfer through the chimney (or flue gas exhaust) and through the boiler's wall. The latter depend in turn on the location of the boiler, the part load ratio of the heating system, the operational conditions of the boiler and the applied control strategy. In EPR, the yearly averaged generation efficiency $\eta_{\text {gen }}$ is calculated based on the $30 \%$ part load ratio of the heating system and corrected for the design return water temperature using Eq. 3:

$$
\eta_{\text {gen }}=f_{\mathrm{Hi} / \mathrm{Hs}}\left(\eta_{30 \%}+0.003 \cdot\left(\theta_{30 \%}-\theta_{\text {mean,boiler }}\right)\right)
$$

with

$$
\theta_{\text {mean,boiler }}=6.4+0.63 \cdot \theta_{\text {return,design }}
$$

where $\mathrm{f}_{\mathrm{Hi}} / \mathrm{Hs}$ is the net-to-gross conversion factor (e.g. $\mathrm{f}_{\mathrm{Hi} / \mathrm{Hs}}=0.9$ for natural gas), $\eta_{30 \% \text {,boiler }}$ is the $30 \%$ part load boiler efficiency based on the manufacturer's data, $\theta_{30 \%}$ is the boiler supply flow temperature at which $\eta_{30 \% \text {,boiler }}$ is determined $\left({ }^{\circ} \mathrm{C}\right)$ and $\theta_{\text {return,de- }}$ sign is the design return flow temperature of the heating system $\left({ }^{\circ} \mathrm{C}\right)$.

The storage system efficiency $\eta_{\text {stor }}$ is assumed to be equal to 1 . 


\section{Building and HVAC system}

Section 3.1 describes the typical building configuration and the users' profile of a representative school and office building in Flanders. In \$3.2, an overview of the properties of the selected HVAC system configuration and related control strategy are given. Both the characteristics as well as the specific details on the design and sizing procedure of the investigated HVAC system (components) are summarized.

\subsection{Building description}

\section{School building model}

A representative (elementary) school building, based on statistical data gathered in previous research [22], is used for this study. The school building is rectangular and consists of two floors of $1028.4 \mathrm{~m}^{2}$ useable floor area each, the floor plan of which can be found in Figure 2. The floor-to-floor height is $2.8 \mathrm{~m}$. The building's total external height is $6.6 \mathrm{~m}$. This results in a protected gross volume of $8147 \mathrm{~m}^{3}, 3694 \mathrm{~m}^{2}$ loss surface (ground floor, roof and external walls) and a compactness level of $2.2 \mathrm{~m}$.
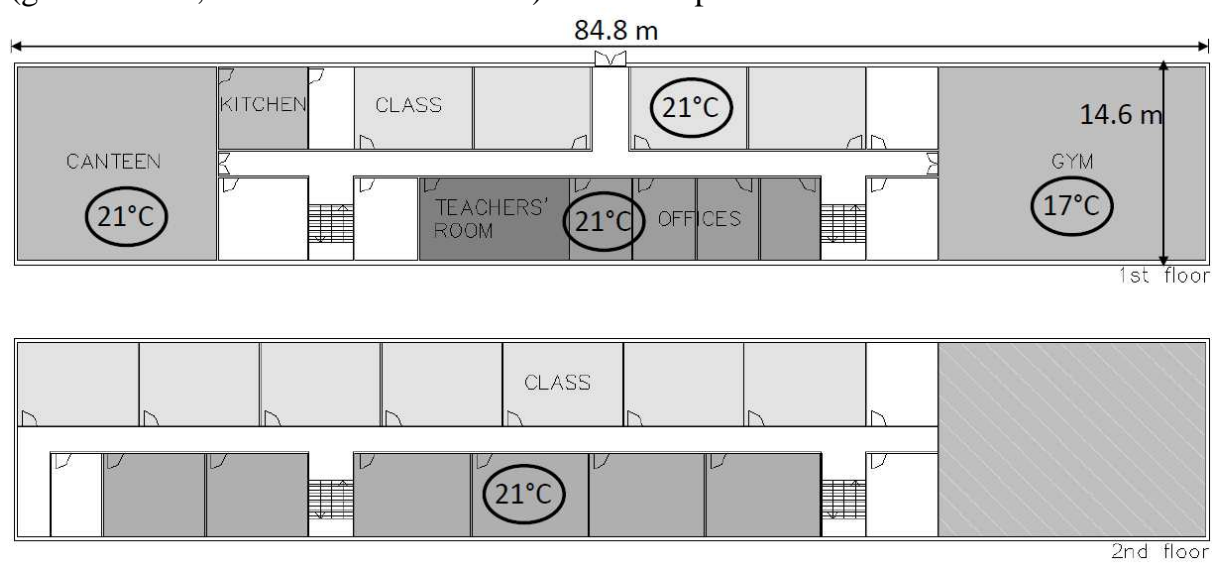

Fig. 2. Floor plan of a representative school building, partitioned in various heating (marked in grayscale) zones with external dimensions. Zonal heating set-point temperatures, set equal to the average heating temperatures in schools [22], are marked.

In Flanders, typically, lessons are evenly spread over five weekdays from Monday to Friday from days 8.30 AM till 4 PM. Wednesday afternoon is free. Other activity and operational characteristics, typical for elementary schools, are summarized in Table 1. Moreover, the zonal set-point temperatures for heating are marked in Figure 2. Additional information on the determination of the building's characteristics and the definition of the boundary conditions can be found in [22]. 
Table 1. Overview of the boundary conditions typical for schools.

\begin{tabular}{|c|c|c|c|c|c|c|c|c|}
\hline & Occupancy & $\begin{array}{l}\text { Occu- } \\
\text { pancy } \\
\text { density } \\
\mathrm{m}^{2} / \text { pers }\end{array}$ & $\begin{array}{l}\text { Ventila- } \\
\text { tion rate }\end{array}$ & $\begin{array}{c}\text { IHG } \\
\text { persons } \\
\text { W/pers }\end{array}$ & $\begin{array}{c}\text { IHG } \\
\text { appliances } \\
\mathrm{W} / \mathrm{m}^{2}\end{array}$ & $\begin{array}{c}\text { Installed } \\
\text { lighting } \\
\text { power }^{(4)} \\
\mathrm{W} / \mathrm{m}^{2}\end{array}$ & $\begin{array}{c}\text { Partial op- } \\
\text { eration ap- } \\
\text { pliances }{ }^{(1)} \\
\%\end{array}$ & $\begin{array}{c}\text { Partial op- } \\
\text { eration } \\
\text { lighting } \\
\%\end{array}$ \\
\hline classroom & $\begin{array}{c}\text { 8.30AM-4PM } \\
87.5 \% \text { nominal } \\
\text { capacity }\end{array}$ & 3 & $\begin{array}{c}29 \\
\mathrm{~m}^{3} /(\text { h.pers }) \\
\text { (S) }\end{array}$ & 60 & 5 & 10.6 & 15 & 90 \\
\hline Office & $\begin{array}{c}\text { 8.30AM-4PM } \\
70 \% \text { nominal } \\
\text { capacity }\end{array}$ & 14 & $\begin{array}{c}29 \\
\mathrm{~m}^{3} / \text { (h.pers) } \\
\text { (S) }\end{array}$ & 80 & 10 & 10 & 50 & 70 \\
\hline Canteen & 12AM-1PM & 1.5 & $\begin{array}{c}29 \\
\mathrm{~m}^{3} / \text { (h.pers) } \\
\text { (S) }\end{array}$ & 60 & 2 & 6 & 100 & 95 \\
\hline Kitchen & $\begin{array}{c}\text { 8.30AM- } \\
2.30 \mathrm{PM}\end{array}$ & 10 & $\begin{array}{c}36 \\
\mathrm{~m}^{3} /(\text { h.pers) } \\
(\mathrm{S})^{(2)}\end{array}$ & 100 & 80 & 10 & 100 & 95 \\
\hline gym & 8.30AM-4PM & 20 & $\begin{array}{c}44 \\
\mathrm{~m}^{3} /(\text { h.pers }) \\
\text { (S) }\end{array}$ & 160 & - & 6 & - & 95 \\
\hline Sanitary & 8.30AM-4PM & - & $\begin{array}{c}15 \\
\mathrm{~m}^{3} /\left(\mathrm{h} \cdot \mathrm{m}^{2}\right) \\
(\mathrm{E})\end{array}$ & - & - & 4 & - & 50 \\
\hline circulation & 8.30AM-4PM & - & (E) & - & - & 2 & - & 50 \\
\hline
\end{tabular}

(1) Appliances and lighting are assumed to be switched on whenever a zone is occupied at a fraction of the nominal capacity, which are expressed by the partial operation factors

(2) Extra ventilation due to heat producing cooking activities $=80 \mathrm{~m} /\left(\mathrm{m}^{2}\right.$ hood.h $)$ during $50 \%$ of the time

\section{Office building model}

A generic reference office building with cellular office spaces is assembled for this research, based on statistical data [19]. The reference building is a detached office building with 4 floors of $500 \mathrm{~m}^{2}$ each, the floor plan of which can be found in Figure 3. The main axis of the building lies in east-west direction (the office zones facades facing south and north). The floor-to-floor height is $3.5 \mathrm{~m}$, hence the building's total height is $14 \mathrm{~m}$. This results in a protected volume of $7000 \mathrm{~m}^{3}, 2680 \mathrm{~m}^{2}$ loss surface and a compactness of $2.6 \mathrm{~m}$. The imposed internal boundary conditions are described in Table 2. The zonal set-point temperatures for heating are marked in Figure 3. 


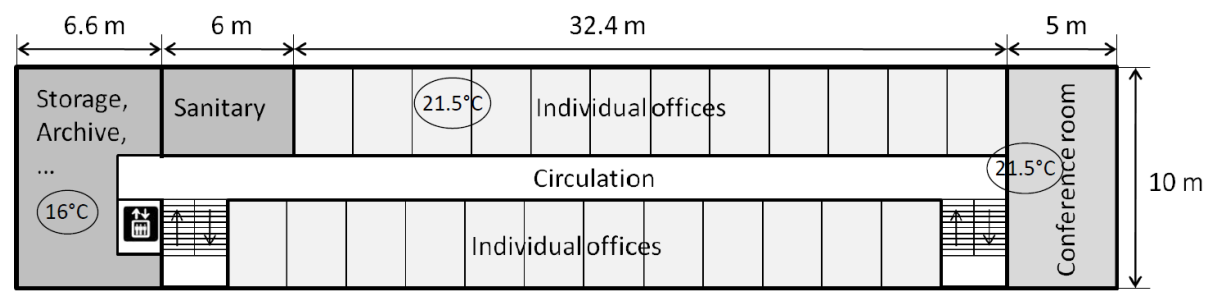

Fig. 3. Floor plan of a representative medium-sized office building. Zonal heating set-point temperatures, set equal to the operative temperatures for a metabolic rate of 1.2 met and clothing value 1 according to [23], are marked.

Table 2. Overview of the boundary conditions typical for office buildings.

\begin{tabular}{|c|c|c|c|c|c|c|}
\hline & Occupancy & $\begin{array}{c}\text { Occu- } \\
\text { pancy } \\
\text { density }{ }^{(1)} \\
\mathrm{m}^{2} / \text { pers } \\
\end{array}$ & $\begin{array}{l}\text { Ventilation rate } \\
\text { (2) }\end{array}$ & $\begin{array}{l}\mathrm{IHG}^{(3)} \\
\text { occupied } \\
\mathrm{W} / \mathrm{m}^{2}\end{array}$ & $\begin{array}{c}\mathrm{IHG}^{(3)} \\
\text { unoccupied } \\
\mathrm{W} / \mathrm{m}^{2}\end{array}$ & $\begin{array}{c}\text { Installed } \\
\text { lighting } \\
\text { power } \\
\text { (4) } \\
\mathrm{W} / \mathrm{m}^{2} \\
\end{array}$ \\
\hline Offices & $\begin{array}{c}\text { 9AM-9PM } \\
\text { 70\% nominal } \\
\text { capacity }\end{array}$ & 10.8 & $\begin{array}{c}36 \mathrm{~m}^{3} /(\text { h.pers }) \\
(\mathrm{S})\end{array}$ & 8.7 & 2 & 11 \\
\hline $\begin{array}{l}\text { Meeting } \\
\text { room }\end{array}$ & $\begin{array}{c}3^{\text {rd }} \text { floor: } \\
\text { 10AM-11AM, } \\
\text { 2PM-3.30PM }\end{array}$ & 3.3 & $\begin{array}{c}36 \mathrm{~m}^{3} /(\text { h.pers }) \\
\text { (S) }\end{array}$ & 15 & - & 11 \\
\hline Sanitary & 8АM-6РM & - & $\begin{array}{c}15 \mathrm{~m}^{3} /\left(\mathrm{h} \cdot \mathrm{m}^{2}\right) \\
\text { (E) }\end{array}$ & - & - & 4.5 \\
\hline Storage & - & - & $3 \mathrm{~m}^{3} /\left(\mathrm{h} \cdot \mathrm{m}^{2}\right)(\mathrm{E})$ & - & - & 3.5 \\
\hline circulation & 8АM-6РM & - & (E) & 8 & 1 & 3.5 \\
\hline
\end{tabular}

(1) Sensible heat gains 1 person $=75 \mathrm{~W}, 60 \%$ of which is convective. Latent heat gains 1 person $=55 \mathrm{~W}$ [24].

(2) $(\mathrm{S})=$ supply, $(\mathrm{E})=$ extraction. $95 \%$ of the supplied fresh air in a zone is assumed to be extracted.

(3) Heat gains due to appliances, based on [25]. Convective and radiative gains are split 50/50.

(4) Lights are assumed to be switched on whenever the zone is occupied. The internal gains are $50 \%$ convective and $50 \%$ radiative.

\subsection{HVAC system}

In schools and office buildings, a large variety of HVAC systems can be found. As system sizing and integrated simulations are very time-consuming, it is unfeasible to include all in this paper. The system selection is therefore limited to an hydronic heating 
system with high temperature radiators, a natural supply and mechanical exhaust ventilation system and passive (night) cooling strategies ${ }^{2}$ to guarantee good summer comfort. Lighting and their according control systems are only considered as a boundary condition (i.e. as a fixed part of the internal heat gains). Finally, as the need for hot water in schools and offices is generally limited, (centralised) production of domestic hot water is not considered. Separate heating circuits are foreseen for each of the building zones characterised by similar (time) trends of thermal loads and/or occupancy patterns. For the school building for example, one heating circuit is foreseen for the administration zone, one for the canteen/kitchen, one for the gym and two heating circuits for the class zone as this zone is additionally split based on the orientation (see Figure 2).

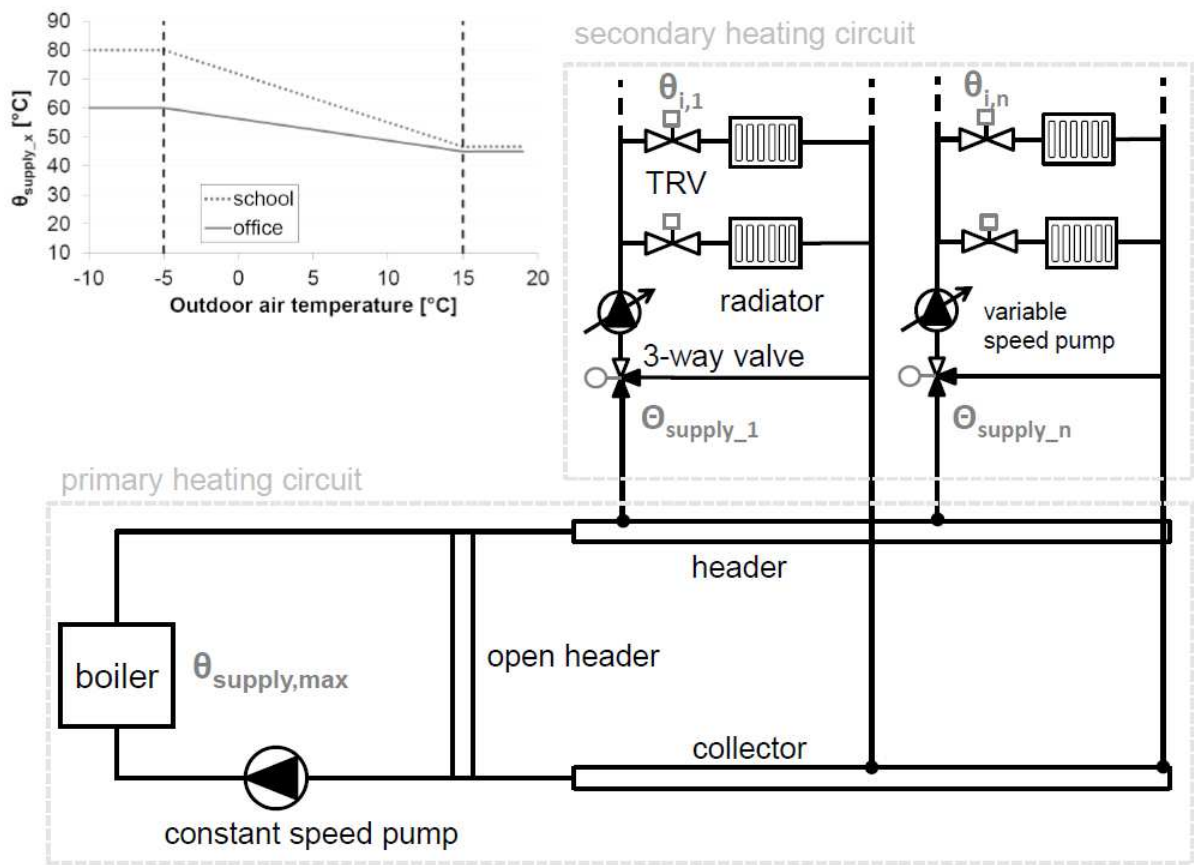

Fig. 4. Conceptual scheme of the investigated heating system configuration as it is implemented in TRNSYS for the school and office building. Real system configurations might deviate.

\footnotetext{
${ }^{2}$ An exhaust ventilation system, used for hygienic ventilation and passive cooling, is commonly found in contemporary Flemish schools [17] though is less typical for office buildings. Nevertheless, as the study focuses on heating systems (see §1) and an hydronic heating system with radiators is regularly found in office buildings, the same HVAC system is selected for both building typologies.
} 
The schematic, conceptual diagram as shown Figure 4 presents in a simplified way the main components of the heating system. It comprises a modulating, condensing gas boiler and radiators controlled by thermostatic valves in every occupied zone. The heat distribution system consists of one central heating circuit and all secondary circuits coupled to a distribution header. The central and secondary circuits are decoupled using an open header. The radiators are sized according to the technical reports of the Belgian Building Research Institute [26] and the European design heat load calculation standard [27]. The typical characteristics of the selected radiator type are shown in Table 3.

Table 3. Characteristics of the selected radiator type

\begin{tabular}{ll}
\hline Radiator characteristics & value \\
\hline Radiator exponent $\mathrm{n}$ & 1.3 \\
Height $(\mathrm{m})$ & 0.9 \\
Specific nominal thermal power $\left(75 / 65 / 20^{\circ} \mathrm{C}\right)(\mathrm{W})$ & 1961 \\
Specific water content $(1 / \mathrm{m})$ & 11.3 \\
Specific weight $(\mathrm{kg} / \mathrm{m})$ & 49.9 \\
Nominal radiative fraction $(\%)$ & 15 \\
\hline
\end{tabular}

All distribution pipes are insulated according to the energy efficiency requirements for technical systems as described in [28]. Pipe diameters are calculated allowing maximum friction losses of $100 \mathrm{~Pa} / \mathrm{m}$ according to [29]. For the secondary circuits where the supply flow rate to the radiators is controlled by thermostatic radiator valves, variable speed pumps are installed. All pumps are sized based on both the design flow and the differential pressure for each of the served zones. The boiler heat output capacity is calculated as the sum of all nominal powers of the emission systems of each zone. A design outdoor temperature of $-8^{\circ} \mathrm{C}$, representative for the Belgian climate, is applied and a safety margin of $10 \%$ for the design heat load capacity of the boiler is foreseen to cover for the distribution losses [30].

Heating is scheduled according to the occupancy profile. After school/working hours and during weekends, the heating is switched off. To reassure good thermal comfort at the start of the day, the heating starts at 7 AM each working day in the office building, and at 4 AM on Mondays and at 5 AM on the other school days in the school building. The zones without a set-point temperature marked (e.g. circulation) are not heated (see Figure 2 and Figure 3). An outdoor temperature reset control is applied on each of the secondary heating circuit separately. The maximum hot water supply temperature is $60^{\circ} \mathrm{C}$ for the office building and $80^{\circ} \mathrm{C}$ for the school ${ }^{3} \mathrm{Hence}$, high design heat loads are found in the school $\left(\max .110 \mathrm{~W} / \mathrm{m}^{2}\right.$ in the school compared to $\max .60 \mathrm{~W} / \mathrm{m}^{2}$ in the office), which explains the selection of a higher maximum supply flow temperature.

3 Class rooms and canteens typically require high ventilation rates (see Table 4). 
The set-point temperature of the boiler is then set equal to the maximum supply temperature of all the secondary heating circuits. An on/off burner control is applied based on the required supply flow set-point temperature: the boiler and boiler pump are turned on as soon as there is heat load and the boiler outlet temperature drops below a minimum (= boiler set-point $-3 \mathrm{~K}$ ). The boiler is switched off when there is no heat load or when the maximum boiler set-point temperature is reached (= boiler set-point $+3 \mathrm{~K}$ ). In between, the power is modulated according to the heat load pattern to reach the required set-point supply flow temperature. To avoid excessive cycling of the boiler, a minimum on/off time of 6 minutes is assumed. The pumps follow this boiler operation regime.

A mechanical exhaust ventilation system is foreseen. Fresh outdoor air is supplied at a constant flow rate in the occupied rooms through trickle vents in the windows. The used air is extracted by extraction fans which are sized according to [31] (IDA 3). The operation of the ventilation fans is controlled by a time schedule according to the zonal occupancy profiles. For the school building, pre-ventilation prior to the school opening hours is applied to reassure good indoor air quality at any time of occupancy [32].

To maintain summer comfort, passive night cooling by mechanical ventilation is used, controlled by multiple control parameters: the night ventilation schedule ( $0 \mathrm{~h}$ $<$ time $<6 \mathrm{~h})$, the star temperature 4 as used in TRNSYS $\left(\theta_{\mathrm{star}}>\theta_{\mathrm{i} ; \mathrm{H} ; \mathrm{set}}\right.$, the outdoor air temperature, and the difference between operative and outdoor air temperature $\left(\theta_{\mathrm{i} ; \mathrm{H} ; \mathrm{op}}\right.$ $\left.\theta_{\mathrm{e}}>2^{\circ} \mathrm{C}\right)[33]$.

\section{Method}

To determine the actual energy performance of a heating system, a series of dynamic, integrated simulations is performed (see section 4.1). Through these simulations, both the impact of the interaction between building and heating system (components) and the mutual interaction between the various subsystems are revealed.

To assess the impact of the interaction between building and system, the investigated heating system is coupled to several building design variants. To obtain these variants, the building (envelope) properties are changed (see section 4.2) while the overall design of the school and office building remains the same.

The energy performance of a heating system depends on the selection of heating system components and their characteristics, the applied sizing procedures, the heating settings and the control strategy used, and the quality of workmanship. For each of the selected systems, the appropriate sizing procedures are followed, the best market available components are selected and current good practice control decisions are made.

\footnotetext{
${ }^{4}$ The star temperature, as used in TRNSYS [34], is the weighted average of the zone air temperature and the surface temperatures of the walls surrounding the zone. This star temperature differs from the operative temperature, which also is a weighted average of the air and mean radiant temperature, but with the weighing factor set equal to 0.5 .
} 
Moreover, the systems are assumed to be well installed and commissioned. The implemented component models are all able to describe part load performance and the influence of non-rated conditions. Transient effects are included as much as possible, as the thermal inertia of the heaviest elements (boiler, radiator) and most of the water or air content of the system (pipes, ducts, boiler, radiator) are modelled. The system thermal losses both during and in between periods of operation are thus mostly accounted for in the simulations. In section 4.3, the most important characteristics and input parameters used for the simulation of all HVAC system components (i.e. fans, pumps, pipes, boilers) are discussed.

\subsection{Integrated dynamic building and HVAC system simulation}

As TRNSYS 17 [34] is well suited for HVAC system studies [35], it is selected as the dynamic simulation tool for this study. The Meteonorm weather file [36] of Brussels is used and the thermal behaviour is studied with a time step of 3 minutes for the school building, which is considered as a good balance between overall simulation time and precision (Peeters et al. (2008)). For the office building, an even smaller time step of 1.5 minutes is used. Figure 5 illustrates in a simplified way the building and coupled heating system as it is implemented in TRNSYS. The considered data flow between the included system components is indicated by the arrows. The entire simulation model is then sequentially solved at every time step, iterating until convergence is reached.

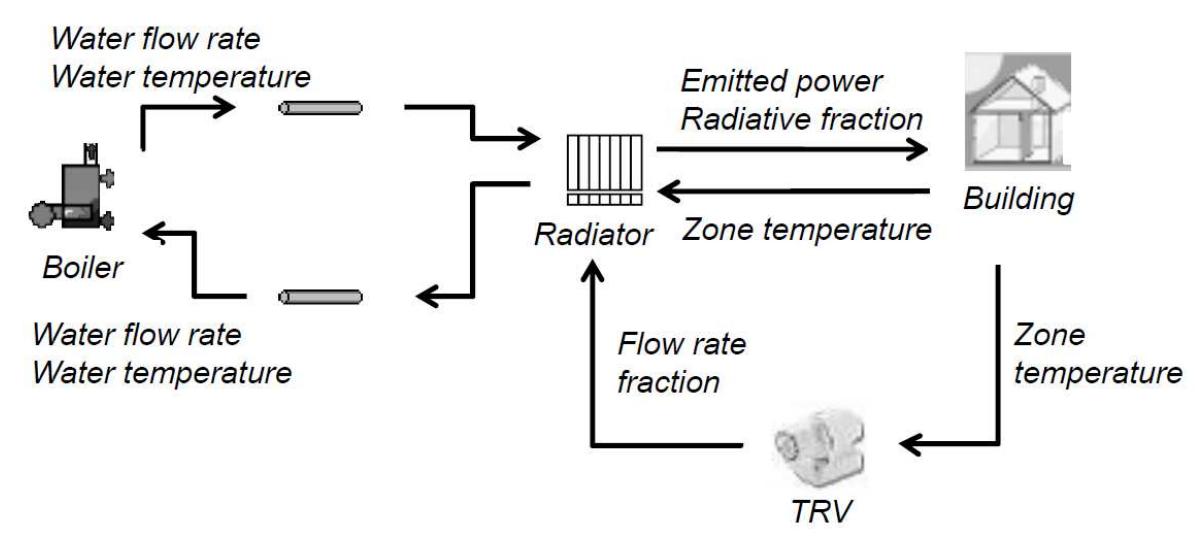

Fig. 5. Illustration of integrated building and HVAC simulation approach in TRNSYS.

For each combination of building and system, two series of dynamic simulations are performed. Series 1 contains the dynamic simulations of the building envelope with ideal assumptions regarding the heating system operation (i.e. infinite heating power, perfect heating control, pure air heating) to calculate the 'ideal' energy demand $\mathrm{Q}_{\mathrm{H} ; \mathrm{nd}}$. To control heating of a building zone, the operative temperature is maintained at the required set-point temperature level. As in the TRNSYS calculation procedure, the air 
temperature is used to control heating or cooling, a simple equation is implemented manipulating the air temperature so that the operative temperature fits the set-point requirements. Series 2 comprises the detailed simulations of both the building and the

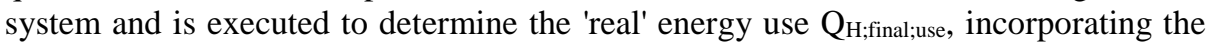
impact of the system (sizing), climatic conditions, and the implementation of operational schedules and control systems. In accordance with the simplified calculation approach (see $\S 1$ ), the results of the dynamic simulations are analysed at subsystem level (generation, distribution and emission) and are determined on a monthly time-base using Eq. 2 to Eq. 6.

The gross energy demand depends on the heat demand of the building $\mathrm{Q}_{\mathrm{H} ; \mathrm{nd}}$ and secondary HVAC system efficiency. The latter is determined by the combination of the emission and distribution losses. The emission losses are caused by temperature stratification, shielding of the emission devices, additional losses to the outside from heating devices embedded in the structure or due to imperfect control of the indoor temperature. The distribution losses are entirely due to thermal losses of the heat distribution pipes which depend on the thermal insulation and length of the distribution pipes, the average temperature of the heating medium and the temperature of the surrounding ambient. It is assumed that none of the pump power is converted into fluid thermal energy.

The secondary HVAC system efficiency $\eta_{\text {sys }}$ is calculated by dividing the energy demand (= results of dynamic simulations Series 1 ) by the gross heat demand (= result of dynamic simulations Series 2):

$$
\eta_{\text {sys }}=\frac{Q_{H, n d}}{Q_{H, \text { gross }}}
$$

The energy delivered to the generation system or the final energy use for heating

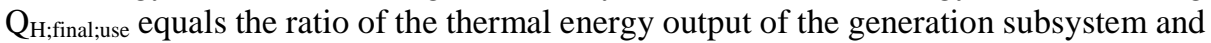
the energy input by the energy carrier. The source of generation efficiency losses depends highly on the type of generation device. For boilers for example, efficiency losses are caused by heat transfer through the chimney (or flue gas exhaust) and through the boiler's wall. The latter depend in turn on the location of the boiler, the part load ratio of the heating system, the operational conditions of the boiler and the applied control strategy. The generation efficiency $\eta_{\text {gen }}$ results from dividing the gross heating demand by the final energy use for heating or the heat input of the boiler.

$$
\eta_{\text {gen }}=\frac{Q_{H, \text { gross }}}{Q_{H, \text { final,use }}}
$$

To link the HVAC system performance to the operation of the system and building properties, the calculated subsystem efficiencies of the considered HVAC system are expressed as a function of the part load ratio of the heating system $\beta$. This particular value is chosen as a reference as it incorporates the effect of the thermal insulation of the building, weather conditions and internal loads and as it is currently applied in [37, 
29,38 ] to determine the subsystem efficiencies. The monthly averaged part load ratio of the heating system $\beta$ is calculated according to Eq. 7:

$$
\beta=\frac{Q_{H, n d}}{\phi_{\text {boiler }} * t_{o p}}
$$

where $\phi_{\text {boiler }}$ is the nominal power the boiler $(\mathrm{kW})$ and top is the number of operational heating hours including the reheat period per month (h). In order to be able to compare the performance of the different building design variants fairly, the resulting thermal comfort in the building needs to be similar in all cases. The thermal comfort is evaluated according to the degree hours' criterion of [32], with the difference between the occurring temperature and the limit temperature as weighting factor. Deviations during 5\% of the occupied time on a yearly and monthly basis are accepted, which means about $60 \mathrm{~h}$ per year and about $7 \mathrm{~h}$ per month for the school buildings, and about $100 \mathrm{~h}$ per year and about $10 \mathrm{~h}$ per month for the office buildings.

\subsection{Building model and characteristics}

Both investigated buildings are modelled as multi-zone buildings (TRNSYS Type56), divided based on the different users' characteristics and heat load patterns of the included rooms. To avoid excessive complexity of the simulation model and to limit the related calculation time, the number of included zones is limited: 1-person offices are modelled as one single zone per floor and orientation (see Figure 3), class rooms are modelled as one zone per orientation (see Figure 2). Moreover, only the 3rd and 4th floor of the office building are modelled in the simulations, assuming their energy demands to be representative for the entire building. This simplification can be justified by the good thermal insulation values of both roof and floor. Both simplifications result in a multi-zone model with 14 thermal zones for the office building and a model with 6 thermal zones for the school building.

To represent a wide range in annual net heating demand and assess the impact of the building's characteristics on the heating (sub)system efficiencies, a selection of school and office building design variants is made (see Table 4 and Table 5). Only those building variants are retained which guarantee good thermal comfort by passive cooling strategies.

\subsection{HVAC system model}

An overview of the main (thermal) component models and related input parameters is given along this section. A detailed mathematical description and information on the input parameters of the models can be found in the TRNSYS manual [34] and in the work of [18]. 
The radiators are modelled by the dynamic, lumped capacitance radiator model TRNSYS Type362 [39] that calculates both the emitted radiator power and the radiative fraction of the emitted power based on the water flow, the surrounding temperature and the incoming water temperature. As in TRNSYS, single (zonal) air temperatures apply and only one-dimensional heat transfer are calculated, locally induced thermal losses of the heat emission systems or additional thermal losses due to temperature stratification in the room are not or hard to be simulated. Hence, to account for these losses, the emitted power of the radiators calculated in TRNSYS is adjusted before being coupled to the building model (TRNSYS Type56) by a fixed value, calculated according to [37]. One heat emitter with a total output capacity equal to the calculated design load is modelled per zone. To determine relevant distribution losses by the simulation model however, a distribution pipe is coupled to the heat emitter with the length equal to the average of all distribution pipes needed to supply the real number of heat emitters. To determine the actual distribution losses, the thermal losses calculated for this pipe are then multiplied by the exact number of heat emitters that are foreseen in the considered building zone. 
Table 4. Selection of 18 design variants of the school building The subsequent letters and numbers in the first column refer to the thermal capacity of the building (Heavy - Light) the considered WWR (20 or 40\%), the orientation (NS or EW) and the building energy efficiency level (variant 1 to 5 ).

\begin{tabular}{|c|c|c|c|c|c|c|c|c|c|}
\hline & $\begin{array}{l}\text { orienta- } \\
\text { tion }\end{array}$ & $\begin{array}{c}\mathrm{U}_{\text {wall }} \\
\mathrm{W} /\left(\mathrm{m}^{2} \mathrm{~K}\right) \\
\end{array}$ & $\begin{array}{c}\mathrm{U}_{\text {roof }} \\
\mathrm{W} /\left(\mathrm{m}^{2} \mathrm{~K}\right) \\
\end{array}$ & $\begin{array}{c}U_{\text {glazing }} \\
\mathrm{W} /\left(\mathrm{m}^{2} \mathrm{~K}\right)\end{array}$ & $\begin{array}{c}\text { g-value } \\
-\end{array}$ & $\begin{array}{c}\mathrm{n}_{50} \\
\mathrm{ACH} \\
\end{array}$ & $\begin{array}{c}\text { WWR } \\
\%\end{array}$ & Shading device ${ }^{(1)}$ & $\begin{array}{l}\text { Thermal capacity } \\
\text { (2) }\end{array}$ \\
\hline H20NS_1 & $\mathrm{N}-\mathrm{S}$ & 0.37 & 0.37 & 1.12 & 0.57 & 3 & 20 & Fixed (S) & heavy \\
\hline H20NS_2 & $\mathrm{N}-\mathrm{S}$ & 0.30 & 0.24 & 1.12 & 0.57 & 2.4 & 20 & Fixed (S) & heavy \\
\hline H20NS_3 & $\mathrm{N}-\mathrm{S}$ & 0.22 & 0.19 & 1.12 & 0.57 & 1 & 20 & Fixed $(\mathrm{S})$, mobile $(\mathrm{E}, \mathrm{W})$ & heavy \\
\hline H20NS_4 & $\mathrm{N}-\mathrm{S}$ & 0.15 & 0.15 & 0.78 & 0.55 & 0.6 & 20 & Fixed $(S)$, mobile $(E, W)$ & heavy \\
\hline H20NS_5 & $\mathrm{N}-\mathrm{S}$ & 0.11 & 0.15 & 0.60 & 0.47 & 0.4 & 20 & Mobile (S,E,W) & heavy \\
\hline H40NS_1 & $\mathrm{N}-\mathrm{S}$ & 0.37 & 0.37 & 1.12 & 0.57 & 3 & 40 & Fixed (S), mobile (E,W) & heavy \\
\hline H40NS_2 & $\mathrm{N}-\mathrm{S}$ & 0.30 & 0.24 & 1.12 & 0.57 & 2.4 & 40 & Fixed $(S)$, mobile $(E, W)$ & heavy \\
\hline H40NS_3 & N-S & 0.22 & 0.19 & 1.12 & 0.57 & 1 & 40 & Fixed $(S)$, mobile $(E, W)$ & heavy \\
\hline H40NS_4 & $\mathrm{N}-\mathrm{S}$ & 0.15 & 0.15 & 0.78 & 0.55 & 0.6 & 40 & Fixed (S), mobile (E,W) & heavy \\
\hline H40NS_5 & $\mathrm{N}-\mathrm{S}$ & 0.11 & 0.15 & 0.60 & 0.47 & 0.4 & 40 & Mobile $(\mathrm{S}, \mathrm{E}, \mathrm{W})$ & heavy \\
\hline L20NS_1 & $\mathrm{N}-\mathrm{S}$ & 0.37 & 0.37 & 1.12 & 0.57 & 3 & 20 & Fixed $(S)$, mobile $(E, W)$ & light \\
\hline L20NS_2 & $\mathrm{N}-\mathrm{S}$ & 0.30 & 0.24 & 1.12 & 0.57 & 2.4 & 20 & Fixed $(S)$, mobile $(E, W)$ & Light \\
\hline L20NS_3 & N-S & 0.22 & 0.19 & 1.12 & 0.57 & 1 & 20 & Fixed (S), mobile (E,W) & light \\
\hline H20EW_1 & E-W & 0.37 & 0.37 & 1.12 & 0.57 & 3 & 20 & Fixed (S) & heavy \\
\hline H20EW_2 & E-W & 0.30 & 0.24 & 1.12 & 0.57 & 2.4 & 20 & Fixed (S) & heavy \\
\hline H20EW_3 & E-W & 0.22 & 0.19 & 1.12 & 0.57 & 1 & 20 & Fixed $(S)$, mobile $(E, W)$ & heavy \\
\hline $\mathrm{H} 20 \mathrm{EW} \_4$ & E-W & 0.15 & 0.15 & 0.78 & 0.55 & 0.6 & 20 & Fixed (S), mobile (E,W) & heavy \\
\hline H20EW_5 & E-W & 0.11 & 0.15 & 0.60 & 0.47 & 0.4 & 20 & Mobile (S,E,W) & heavy \\
\hline
\end{tabular}

(1) Fixed = horizontally placed louvres. Mobile = automatically controlled screens, controlled on irradiati

(2) Heavy = heavy walls, roof and floor; $C_{m}=95 \mathrm{Wh} /\left(\mathrm{m}^{2} \mathrm{~K}\right)$. Light $=$ heavy floor but light roof, external and internal walls; $\mathrm{C}_{\mathrm{m}}=43 \mathrm{Wh} /\left(\mathrm{m}^{2} \mathrm{~K}\right)$. 
Table 5. Selection of 5 design variants of the office building varying the building envelope efficiency, shading and WWR. All main façades face north and south.

\begin{tabular}{lccccccl}
\hline $\begin{array}{l}\text { Net heat } \\
\text { demand } \\
\mathrm{kWh} /\left(\mathrm{m}^{2} . \mathrm{a}\right)\end{array}$ & $\begin{array}{c}\mathrm{U}_{\text {wall }} \\
\mathrm{W} /\left(\mathrm{m}^{2} \mathrm{~K}\right)\end{array}$ & $\begin{array}{c}\mathrm{U}_{\text {roof }} \\
\mathrm{W} /\left(\mathrm{m}^{2} \mathrm{~K}\right)\end{array}$ & $\begin{array}{c}\mathrm{U}_{\text {glazing }} \\
\mathrm{W} /\left(\mathrm{m}^{2} \mathrm{~K}\right)\end{array}$ & $\begin{array}{c}\mathrm{g}- \\
\text { value } \\
-\end{array}$ & $\begin{array}{c}\mathrm{n}_{50} \\
\mathrm{ACH}\end{array}$ & $\begin{array}{c}\text { WWR } \\
\%\end{array}$ & $\begin{array}{l}\text { Shading } \\
\text { device }\end{array}$ \\
\hline 22.6 & 0.30 & 0.30 & 1.1 & 0.59 & 2.5 & 21 & No \\
20.1 & 0.20 & 0.20 & 1.1 & 0.26 & 1.0 & 31 & No \\
26.5 & 0.40 & 0.30 & 1.1 & 0.44 & 2.5 & 21 & Fixed (S) \\
33.7 & 0.40 & 0.30 & 1.1 & 0.26 & 2.5 & 71 & Fixed (S) \\
37.0 & 0.60 & 0.40 & 1.1 & 0.29 & 2.5 & 31 & Fixed (S) \\
\hline
\end{tabular}

(1) Fixed $=$ horizontally placed louvres $($ TRNSYS type200a). Width slats $=20 \mathrm{~cm}$, distance between slats $=$ $19.5 \mathrm{~cm}$

The thermostatic radiator valves on the radiators are modelled based on the IEA annex 10 's perfect thermostatic valve model as developed by [40]. It is a lumped capacitance model of the temperature sensor including the (relatively small) thermal resistance of the casing and the (larger) resistance between the sensor and the water. The valve authority is set equal to 0.7 . The hysteresis is $0.5^{\circ} \mathrm{C}$ and the nominal and maximal temperature differences between the valve and ambient are assumed to be $2^{\circ} \mathrm{C}$. All valves are assumed to have an infinite range ability: $100 \%$ of the maximum flow rate when the valve is fully open and $0 \%$ of flow rate when fully closed.

For the simulation of the distribution pipes, the 'plug-flow' pipe model (TRNSYS Type31) is used. The surrounding temperatures of the pipes are simulated by the thermal simulation model and used as an input for the pipe models. In line with the simplified calculation approach as applied in EPR [3], the distribution thermal losses which occur in heated zones are considered recoverable and are consequently considered injected as heat gains in the zones which they serve.

For the dynamic simulations of the dynamic boiler, the boiler model developed by [41] (TRNSYS Type869) is chosen. This model uses the incoming water flow rate and temperature as inputs and calculates the hot water outlet temperature and the related energy use. Parameters are the nominal range of thermal powers $\left(\phi_{\text {nom }}\right)$, the thermal capacitance of the burner $\left(\mathrm{C}_{\text {burner }}\right)$, the water content $\left(\mathrm{V}_{\mathrm{w}}\right)$, the UA-value of the boiler and the auxiliary electrical energy use $(\mathrm{W})$. The values for the boilers used in this research are listed in Table 6, taken from the technical data from a leading manufacturer.

Table 6. Parameter values of gas boilers used in this research.

\begin{tabular}{lcccccccc}
\hline & $\begin{array}{c}\Phi_{\text {nom,max }} \\
\mathrm{kW}\end{array}$ & $\begin{array}{c}\Phi_{\text {nom,min }} \\
\mathrm{kW}\end{array}$ & $\begin{array}{c}\mathrm{C}_{\text {burner }} \\
\mathrm{kJ} / \mathrm{K}\end{array}$ & $\begin{array}{c}\mathrm{V}_{\mathrm{W}} \\
\mathrm{m}^{3}\end{array}$ & $\begin{array}{c}\mathrm{UA} \\
\mathrm{kJ} /(\mathrm{K} . \mathrm{h})\end{array}$ & $\begin{array}{c}\mathrm{W}_{\text {aux,min }} \\
\mathrm{W}\end{array}$ & $\begin{array}{c}\mathrm{W}_{\text {aux,max }} \\
\mathrm{W}\end{array}$ & $\begin{array}{c}\mathrm{W}_{\text {aux }, \text { off }} \\
\mathrm{W}\end{array}$ \\
\hline Office & 142 & 47 & 94.5 & 0.221 & 46.52 & 45 & 185 & 30 \\
School & 311 & 104 & 128 & 0.279 & 77.22 & 55 & 385 & 30 \\
\hline
\end{tabular}


One should keep in mind that, despite the level of detailing of the integrated model, some realistic effects that influence the building energy use are neglected either due to inherent restrictions of the simulation model (e.g. realistic variations of the emission efficiencies cannot be calculated) or due to the modelling assumptions made (i.e. the impact of hydraulic imbalances or improper design on the efficiency of the HVAC system cannot be assessed in TRNSYS, so all components are assumed to be correctly installed and are connected to well-balanced hydraulic circuits which is however highly unlikely in real buildings).

\section{$5 \quad$ Results and discussion}

In this section, the results of the integrated building and system simulations are discussed and analysed. For all cases, the desired thermal comfort levels (winter and summer) of all building zones are checked and found satisfactory, indicating that all system components were properly sized for every respective building design variant, and that the applied control strategy works well.

\subsection{Final energy use for heating}

Figure 6 and 7 show the monthly final energy use for heating $\mathrm{Q}_{\mathrm{H} \text {;final;use }}$ in relation to the monthly heating demand $\mathrm{Q}_{\mathrm{H} ; n d}$ for the school and office buildings respectively. Linear trend lines are added to both figures to assess the feasibility of the use of a constant value for the overall system efficiency to express the energy use as a function of the heat demand (i.e. in conformity with EPR - see $\S 1$ ). The trend lines are forced to go through the origin to be physically correct.

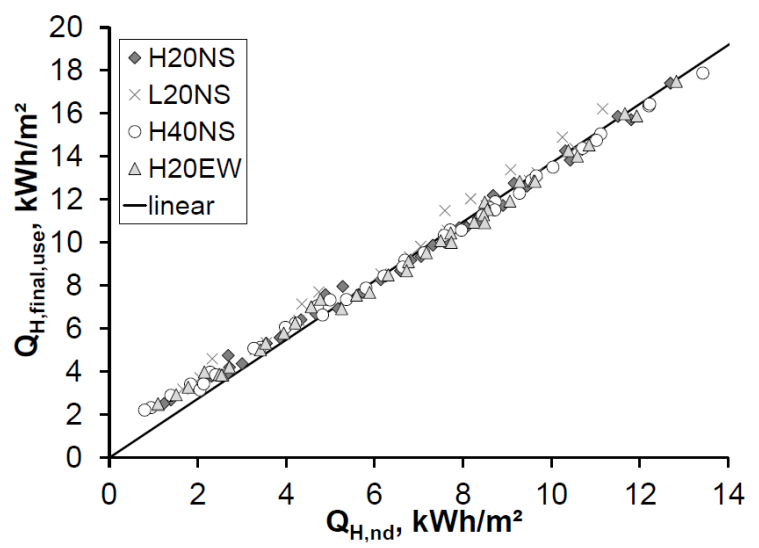

Fig. 6. Monthly final energy use for heating ( $\mathrm{QH}$;final;use) expressed as a function of the monthly heat demand $(\mathrm{QH} ; \mathrm{nd})$, both normalised to the building floor area $\left(\mathrm{kWh} / \mathrm{m}^{2}\right)$, for the 18 school building design variants. 


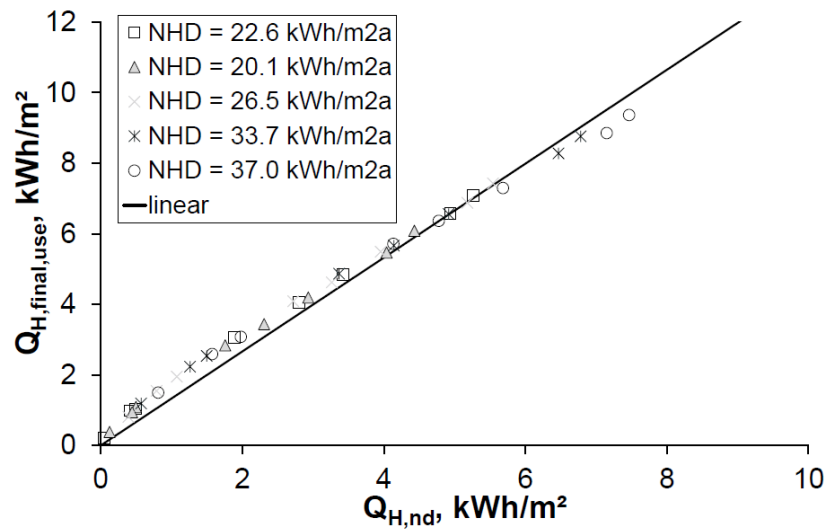

Fig. 7. Monthly final energy use for heating ( $\mathrm{QH}$;final;use) expressed as a function of the monthly heat demand $(\mathrm{QH} ; \mathrm{nd})$, both normalised to the building floor area $\left(\mathrm{kWh} / \mathrm{m}^{2}\right)$, for the 5 office building design variants.

Figure 6 and Figure 7 show an almost linear correlation $\left(\mathrm{R}^{2}=0.98\right)$ between $\mathrm{Q}_{\mathrm{H} \text {;final;use }}$ and $\mathrm{Q}_{\mathrm{H} \text {;nd }}$, except for the lowest heat demands where the decrease of the system effi-

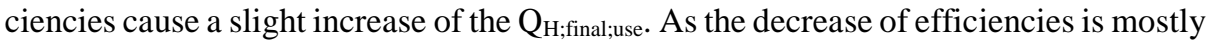
noticed in periods of low part load ratios and thus low heat demands, the effect on the annual energy use is limited.

On the other hand, when comparing the results of the dynamic simulations with the results of the EPR-tool, significant differences are revealed (see Figure 8).

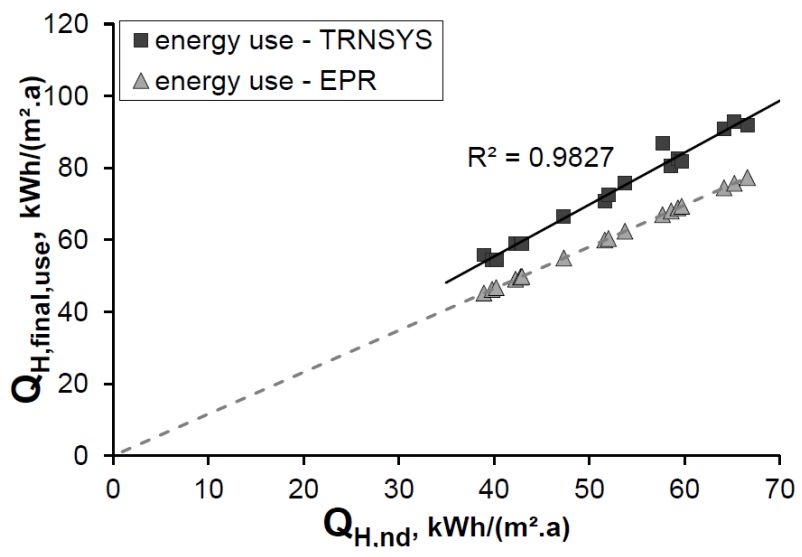

Fig. 8. $\mathrm{QH} ;$ final;use expressed as a function of $\mathrm{QH}$;nd, both normalised to the building floor area $\left(\mathrm{kWh} /\left(\mathrm{m}^{2} \mathrm{a}\right)\right)$, for HVAC1 coupled to 18 different school building design variants, calculated in TRNSYS or using the EPR [3] calculation standard. 
The results of the integrated dynamic simulations show that the thermal losses of the heating systems add approximately 25 to $30 \%$ to the net heating demand for school buildings. These additional losses are clearly underestimated by the EPR-tool as $\mathrm{Q}_{\mathrm{H} \text {,final,use,EPR }}$ is on average $16 \%$ or $11.8 \mathrm{kWh} /\left(\mathrm{m}^{2}\right.$.a) lower than $\mathrm{Q}_{\mathrm{H} \text {,final,use,dyn. The max- }}$ imum difference of $29 \%$ is found for the light design variant with a WWR $=20 \%$ and the main axis oriented along the North South direction (L20NS 1). Similar results are found for offices [18].

\subsection{HVAC subsystem efficiencies}

The results of the dynamically calculated and monthly averaged emission, distribution and generation efficiency for all school and office building design variants are shown in Figure 9. To visualise the relation of the heating system performance to the operation of the system and the building properties, the efficiencies are plotted in relation to the part load ratio of the heating system $\beta$ (see Eq. 7). Overall, three phenomena - similar for the school and office buildings - are noticed.

(i) The efficiencies decrease significantly when part load ratios of the heating system $\beta$ are lowered, especially noticeable for the emission efficiencies. Similar results were found earlier [14, 15] for emission efficiencies. Both studies indicate the decrease of control efficiencies at low part load ratios as the most important cause: when highly fluctuating internal and solar heat gains occur, accurate control of the heating system becomes more difficult so heat outputs result easily in overheating and affect negatively the control efficiencies.

(ii) Figure 9 (a) to (f) demonstrates that the emission efficiencies $\eta_{\mathrm{em}}$ are significantly influenced by the buildings' characteristics whereas the distribution $\eta_{\text {dis }}$ and generation efficiencies $\eta_{\text {gen }}$ are not. To visualise the impact, two additional graphs are plotted which show the effect of the thermal capacity (heavy - light), the solar heat gains (i.e. WWR $=20 \%-40 \%$ ) and the insulation level (variant 1, 3 and 5 - see Table 4) of the building on the emission efficiencies for the school building (see Figure 10 (a) and (b)). Figure 10 (a) shows that overall slightly lower emission efficiencies are obtained in lighter buildings. Figure 10 (b) shows that lower emission efficiencies are found for those school building variants with a window-to-wall ratio equal to $40 \%$, hence for buildings with more solar heat gains. The impact of the insulation level of the building is not as straightforward as different results are found for the winter and the mid-season. In winter months, emission efficiencies are slightly higher in better insulated buildings. As however the heating system and related control settings are designed in accordance to the buildings' characteristics [27], overall the impact of the insulation level remains limited. An opposite trend is noticed in spring and autumn months when higher solar heat gains occur and accurate control of the heating system becomes more challenging. As shown in Figure 10 (b), this trend is more pronounced in more energy efficient buildings. 


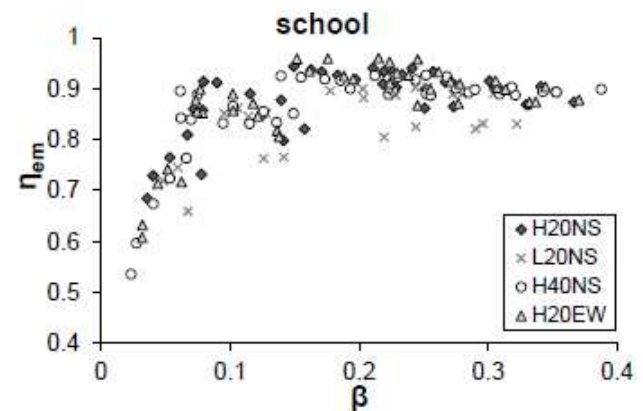

(a) Emission.

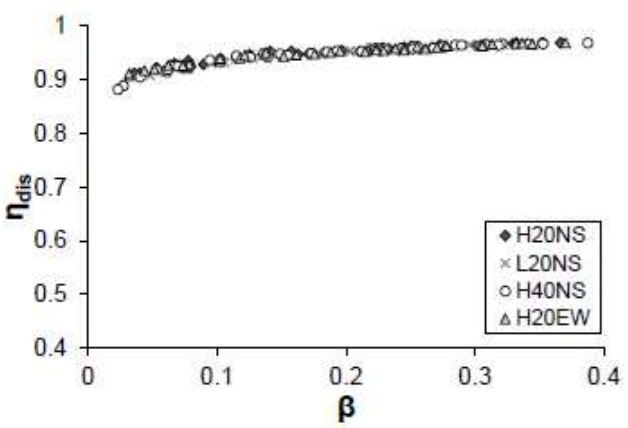

(c) Distribution.

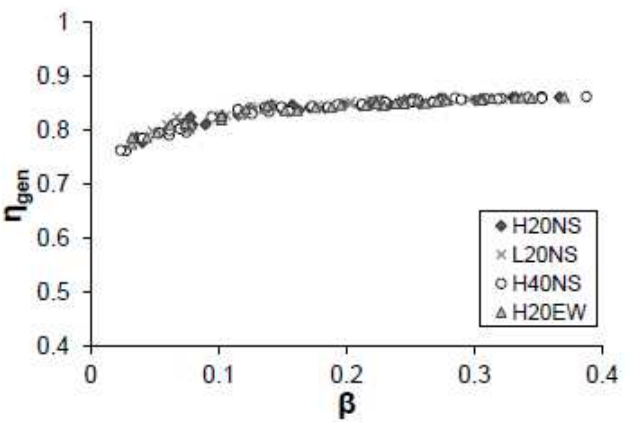

(e) Generation.

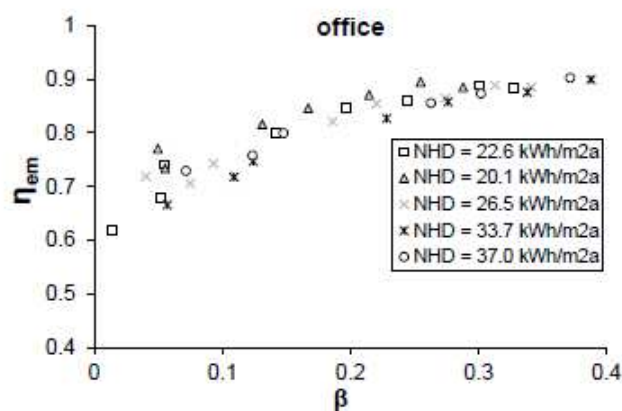

(b) Emission.

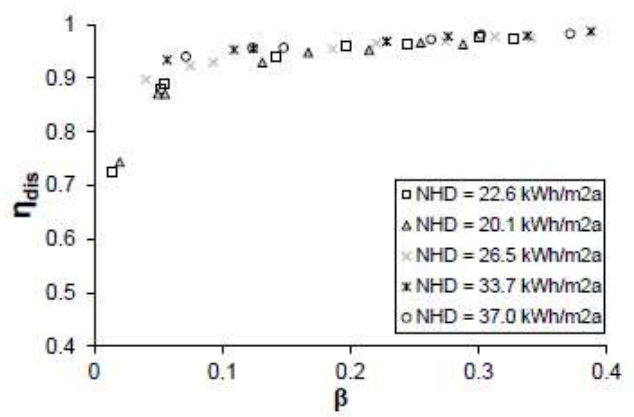

(d) Distribution.

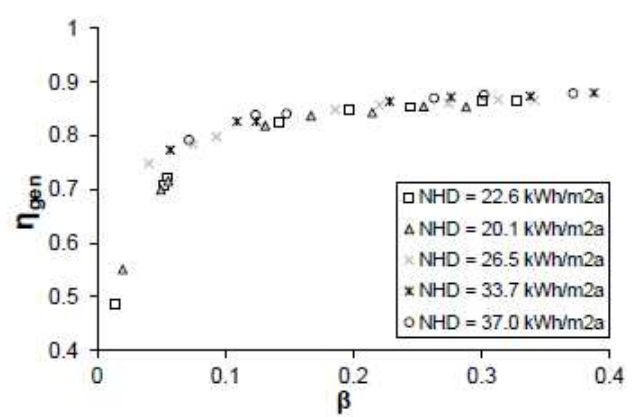

(f) Generation.

Fig. 9. Monthly averaged $\eta_{e m}, \eta_{\text {dis }}$ and $\eta_{g e n}$ for all school and office building design variants in function of the part load ratio of the heating system $\beta$. 


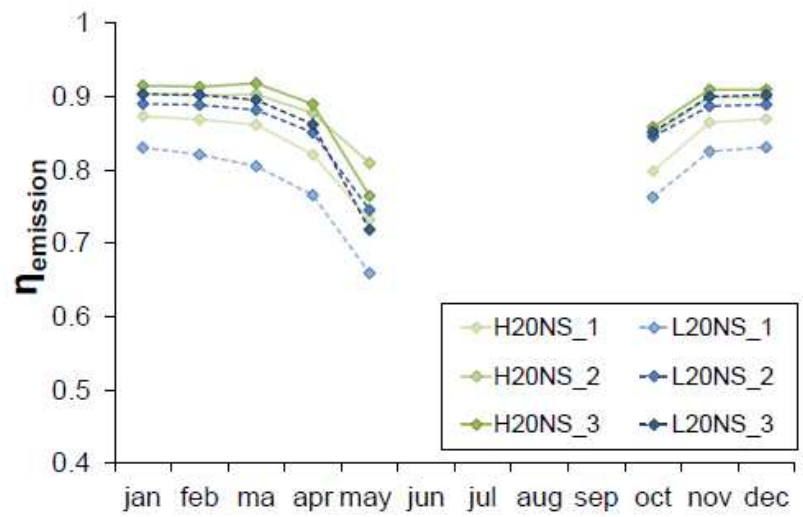

(a) Thermal capacity.

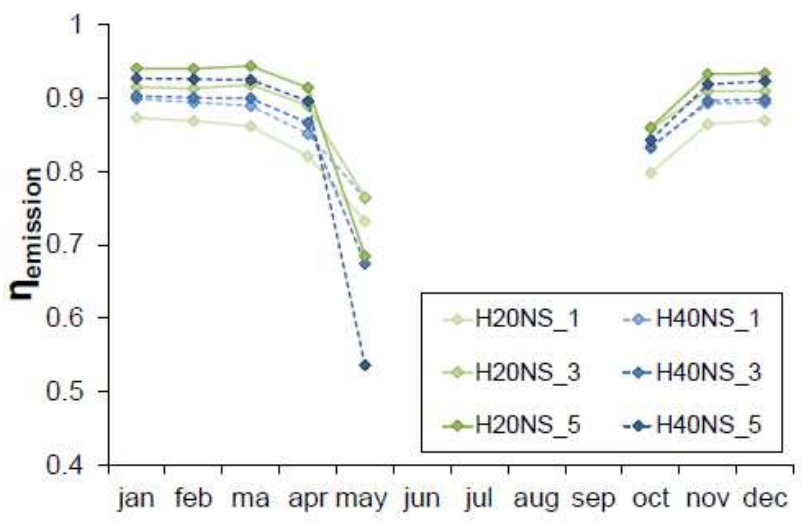

(b) WWR.

Fig. 10. Impact of the buildings characteristics (i.e. thermal capacity, U-value and WWR) on the monthly averaged $\eta_{\mathrm{em}}$ in the school building.

(iii) Overall, rather low values of the generation efficiencies $\eta_{\text {gen }}$ are found. This can mostly be explained by the low part load ratios. According to the heating system design standard [27], boilers are sized as the sum of the design heat loads of all heated zones. In addition, a reheat capacity is included while, simultaneously, all solar and internal heat gains are neglected. Considering the typically high internal heat gains in class rooms and offices, this results in frequent low part load ratios, related excessive cycling 
and extra thermal losses of the boiler, which cause in turn a loss of the generation efficiency. Furthermore, the use of an open header in combination with a constant speed pump in the primary heating circuit negatively affects the generation efficiency: as the return water flow is mixed with the 'unused' part of the supply hot water flow, an increased return water flow temperature is found and hence lower efficiencies of the boiler are obtained. The thermal losses of the boiler related to the boiler operating conditions (i.e. expressed by the part load ratio $\beta$ ) and the return water flow temperature at bypass operation of the boiler are hence important influencing factors and should be accurately modelled by the calculation method used for the assessment of the HVAC system performance.

The following overall conclusions can be drawn:

- The subsystem efficiencies decrease significantly when part load ratios $\beta$ are low. As the losses of the efficiency are only noticed in periods of low heat demands, it is shown that the overall effect on the annual energy use is be limited.

- The control efficiency of the HVAC systems is affected by the characteristics of the building to which the HVAC system is coupled. Especially for the lighter buildings, a lower performance of the control efficiencies is noticed. Variations over the other three building design variants (i.e. H20NS, H40NS and H20EW) remain however limited to $<10 \%$.

- The final energy use for heating is significantly underestimated by the EPR standard [3] mainly due to a high overestimation of the generation efficiencies. Dynamic simulation results show that the generation efficiencies depend highly on the hot water temperature regime (i.e. heating curve, return temperature) and the part load ratios of the heating systems. Based on the comparative analysis of the static and dynamic calculated efficiencies, these effects appear however to be underestimated in the currently applied EPR calculation method. Adding supplementary data to take into account the specific boiler operation conditions of the individual installation and including the option to calculate the impact of recirculation (i.e. bypass) on the return water temperature, could offer a better fit and could thus be a more accurate alternative for the EPR calculation standard.

Other alternative heat generation, distribution and emission systems, likely to be found in contemporary offices and schools, are not studied here. Additional research is hence necessary to check if the use of the simplified calculation approach can be extrapolated to other HVAC system (configurations), control systems, etc. Moreover, the study focuses on the conceptual framework of the simplified calculation method only. Further research is necessary to assess the accuracy of the values of the yearly averaged subsystem efficiencies as currently defined in the simplified calculation standard. 


\section{Conclusion}

This paper assesses the accuracy of the simplified calculation approach to determine the final energy use for heating in non-residential buildings in the framework of the EPBD. Integrated, dynamic simulations of a traditional HVAC system used in a school and office building are performed. The system consists of a modulating condensing gas boiler and radiators in every heated zone. No active cooling is provided; though acceptable summer comfort levels are guaranteed using passive (night) cooling strategies. Hygienic ventilation is foreseen by a mechanical exhaust ventilation system. To obtain a comprehensive set of analysis results, the investigated heating system is coupled to 18 school building design variants on the one hand, and 5 office building variants on the other hand.

Based on the integrated simulation results, the influence of both the buildings' characteristics and the system operation on the heating system performance is analysed. To do so, monthly efficiencies for the heat generation, distribution and emission subsystems are deduced, expressed as a function of the part load ratio of the heating system. Regarding the impact of the building's characteristics, the results reveal that for the investigated, rather well insulated building variants, the impact on the (sub)system efficiencies is limited. No impact is found on the heat generation and distribution efficiencies. The variations of the control efficiency of the heating emission systems due to varying characteristics of the building to which the system is coupled remain $<10 \%$.

Regarding the heating system operation, a decrease of the (sub)system efficiencies is noticed when part load ratios of the heating system decrease. Nevertheless, as the losses of efficiency are only noticed in periods of low part load ratios and hence low heat demands, the overall effect on the annual final energy use for heating is limited.

Finally, it is shown that the simplified calculation approach using a single coefficient to express the final energy use as a function of the heat demand offers good calculation results. For schools, the root mean square error is limited to $2 \mathrm{kWh} /\left(\mathrm{m}^{2}\right.$.a) or $2.4 \%$. For, the office buildings, the maximum RMSE is $2.4 \mathrm{kWh} /\left(\mathrm{m}^{2} . \mathrm{a}\right)$ or $9.9 \%$.

Despite the uncertainties and restrictions of the investigated simulation model, one may conclude the simplified approach as currently applied in the EPR calculation tool in Flanders is suited for the calculation of the final energy use. An evaluation of tabulated values for the overall system efficiencies used in this simplified method, based on more extensive dynamic simulation results, is however recommended.

\section{References}

1. EPBD, The revised Energy Performance of Buildings Directive (EU) 2018/844, 2018

2. VEA, Annex V Bepalingsmethode van het peil van primair energieverbruik van woongebouwen." Brussels, Belgium, 2017

3. VEA, Annex VI Bepalingsmethode van het peil van primair energieverbruik van kantooren school- gebouwen (in Dutch).” Brussels, Belgium, 2015 
4. Van Dijk, H.A.L., Spiekman, M.E., De Wilde, P.A., A monthly method for calculation energy performance in the context of European building regulations." In 9th International IBPSA Conference, 255-262. Montreal, Canada, 2005

5. Van Dijk, H.A.L., Spiekman, M.E., Energy performance of buildings: Outline for harmonised EP procedures (ENPER - TEBUC). Technical report. Delft, The Netherlands: TNO Building and Construction Research, 2004

6. Van der Veken, J., Creylman, J., Lenaerts, T., Studie naar kostenoptimale niveaus van de minimumeisen inzake energieprestaties van nieuwe residentiele gebouwen (in Dutch). Technical Report april. Geel, Belgium: Kenniscentrum Energie, Thomas More Kempen/KU Leuven, 2013

7. De Deygere, M., Troch, E., Studie naar kostenoptimale energieprestatie- eisen bij nietresidentiele gebouwen (in Dutch). Technical report. Brussel, Belgie: Vlaams Energie Agentschap (VEA), 2013

8. Pernigotto, G., Evaluation of building envelope energy performance through extensive simulation and parametrical analysis." Phd. University of Padova, Italy, 2013

9. Zhang, Y., Wright, J.A., Hanby, V.I., Energy aspects of HVAC system configurations Problem definition and test cases." HVAC and R Research 12 (3 C): 871-888, 2006

10. Van der Veken, J., Hens, H., Determination of the heating efficiency at building level." In Building Physics Symposium, 101-104. Liege, Belgium, 2008

11. Shahrestani, M., Runming, Y., Cook, G.K., Characterising the energy performance of centralised HVAC\&R systems in the UK." Energy and Buildings 62: 239-247. http://linkinghub.elsevier.com/retrieve/pii/S0378778813001849, 2013

12. Korolija, I., Heating, ventilating and air-conditioning system energy demand coupling with building loads for office buildings.” Phd. De Montfort University, Leicester, UK, 2011

13. Peeters, L., Van der Veken, J., Hens, H., Helsen, L., D'haeseleer, W., Control of heating systems in residential buildings: Current practice." Energy and Buildings 40 (8): 14461455. http://linkinghub.elsevier.com/retrieve/pii/S0378778808000315, 2008

14. Van der Veken, J., De Meulenaer, V., Hens, H., Eindrapport GBOU - EL2EP PROJECT: Ontwikke- ling via levenscyclusoptimalisatie van extreem lage energie- en pollutiewoningen (in Dutch). Technical report, 2006

15. Bauer, M., "Methode zur Berechnung und Bewertung des Energieaufwandes fur die Nutzenubergabe bei Warmwasserheizanlagen." Ph.D. thesis. Universitat Stuttgart, Germany, 1999

16. DIN V 4701-10, Energy efficiency of heating and ventilation systems in buildings - Part 10: Heating, domestic hot water, ventilation. no. 0033, 2003

17. Wauman, B., Evaluation of the quasi-steady-state method for the assessment of energy use in school buildings." Ph.D. thesis. KU Leuven, 2015

18. Parys, W., Cost optimization of cellular office buildings based on building energy simulation.” Phd. KU Leuven, Belgium. Leuven, Belgium, 2013

19. BBRI, Kantoor2000 - Studie van energiegebruik en binnenklimaat van kantoren (in Dutch). Technical report. BBRI, 2001

20. Korolija, I., Marjanovic-Halburd, L., Zhang, Y., Hanby, V., UK office buildings archetypal model as methodological approach in development of regression models for predicting building energy consumption from heating and cooling demands." Energy and Buildings 60: 152-162. http://linkinghub.elsevier.com/retrieve/pii/S0378778812006810, 2013 
21. Tchervilov, L., Kaloyanov, N.G., Study on energy efficiency in buildings in the contracting parties of the energy community - Final report. Technical Report February. Energy Saving International AS (ENSI), 2012

22. Wauman, B., Saelens, D., Breesch, H., The definition of representative boundary conditions for Flemish schools for use in energy assessment methods." Energy and Buildings 87: 1-13. http://linkinghub.elsevier.com/retrieve/pii/S0378778814008780, 2015

23. ISO 7730, Ergonomics of the thermal environment - Analytical determination and interpretation of thermal comfort using calculation of the PMV and PPD indices and local thermal comfort criteria. http://linkinghub.elsevier.com/retrieve/pii/S0267726105000503, 2005

24. ASHRAE. ASHRAE fundamentals. 2009

25. Wilkins, C., Hosni, M.H., Heat gain from office equipment, ASHRAE journal 42, 33-44, New York, 2000.

26. Debruyne, R., Rapport nr. 14: ontwerp en dimensionering van centrale-verwarmingsinstallaties met warm water (in Dutch). Technical Report 14. Brussels, Belgium: WTCB, 2013

27. NBN EN 12831, Verwarmingssystemen in gebouwen - Methode voor de berekening van de ontwerp- warmtebelasting, 2003

28. VEA, Bijlage XII: Systeemeisen (in Dutch).” Brussels, Belgium, 2011

29. EN 15316-2-3, Heating systems in buildings - Method for calculation of system energy requirements and system efficiencies - Part 2-3 : Space heating distribution systems, 2007

30. NBN D 30-001, Centrale verwarming, ventilatie en luchtbehandeling - Gemeenschappelijke eisen voor alle systemen - Warmtegeneratoren en branders, 1991

31. NBN EN 13779, Ventilation for non-residential buildings - Performance requirements for ventilation and room-conditioning systems (in Dutch), 2010

32. EN 15251, Indoor environmental input parameters for design and assessment of energy performance of buildings addressing air quality, thermal environment, lighting and acoustics, 2007

33. Breesch, H., "Natural night ventilation in office buildings." Phd. UGent, Belgium. Ghent, Belgium, 2006 [33]

34. Klein, S.A., Beckham, W.A., Mitchell, D.W., TRNSYS 17.1: A Transient System Simulation Program, Solar Energy Laboratory, University of Wisconsin, Madison, USA, 2010

35. Crawley, D.B., J. Hand, M. Kummert, and B.T. Griffith, Contrasting the capabilities of building energy performance simulation programs (version 1.0). Technical Report July, US Department of Energy, University of Strathclyde Energy Systems Research Unit, University of Wisconsin Solar Energy Laboratory, National Renewable Energy Laboratory, 2005

36. Meteonorm, Meteotest. Meteonorm versie 5.1 - Edition 2005, 2005

37. EN 15316-2-1, Heating systems in buildings - Method for calculation of system energy requirements and system efficiencies - Part 2-1: Space heating emission systems, 2007

38. EN 15316-4-1, Heating systems in buildings. Method for calculation of system energy requirements and system efficiencies. Space heating generation systems, combustion systems (boilers), 2008

39. Holst, S. "TRNSYS - Models for radiator heating systems." Munchen, Germany, 1996

40. Ast, H., IEA - Annex 10: Thermostatic valves. Technical report. Stuttgart, Germany: Institut fur Kernenergetik un Energiesysteme, abt. Heizung, Luftung-Klimattechnik, Universitat Stuttgart, 1986. 
41. Haller, M., Konersmann, L., Haberl, R., Droscher, A., Frank, E., "Comparison of different approaches for the simulation of boilers using oil, gas, pellets or wood chips." In 11th International IBPSA Conference, 732-739. Glasgow, Schotland, 2009 